\title{
Vegetative and Reproductive Variability of Dictyota crenulata (Phaeophyta: Dictyotales) along the Central and Southwestern Gulf of California, México ${ }^{1}$
}

\author{
María del Carmen Altamirano-Cerecedo $0^{2,3}$ and Rafael Riosmena-Rodríguez ${ }^{3}$
}

\begin{abstract}
Dictyota crenulata J. Agardh is widely distributed throughout the Gulf of California. Comparative analyses of morphology, anatomy, and reproductive features of this species were conducted along the central western and southwestern regions of the Gulf of California. Thalli showed geographical variations in length and apical width. No differences were observed in anatomy of vegetative thalli or relative abundance of reproductive structures. Dictyota crenulata had unilayered or multilayered medullas in the basal region and in proliferations. Most thalli presented unilayered medullas in the middle section. Our observations indicate that number of medullary layers is indeed a phenotypically plastic character, in agreement with previously published results. Variations in thallus morphology such as proliferations and length are likely the result of environmental differences, also reflected in the reproduction of $D$. crenulata. The southwestern region had the highest percentage of all life cycle stages (female gametophytes and sporophytes, both $22 \%$, and vegetative thalli, $14 \%$ ). Our results demonstrate morphological variability in Dictyota crenulata across its distribution in the Gulf of California.
\end{abstract}

Species of the genus Dictyota Lamouroux are common elements of the tropical and subtropical marine flora (De Clerck and Coppejans 1999). Generic delimitation in the Dictyotales mostly has been based on morphological and anatomical characters (Womersley 1987, Phillips 1997, Lee and Bae 2002). Unfortunately most of the vegetative characters that form the basis of the generic classification show extensive variation (De Clerck and Coppejans 2003), principally in

\footnotetext{
${ }^{1}$ Fieldwork was sponsored by the University of California Institute for Mexico and the United States (UCMEXUS) (grant to S. Gaines and R.R.-R.) and Comisión Nacional para el Conocimiento y Uso de la Biodiversidad (CONABIO) (grant S074 to R.R.-R.). Manuscript accepted 21 December 2006.

${ }^{2}$ Corresponding author (malt@uabcs.mx).

${ }^{3}$ Programa de Investigación en Botánica Marina, Universidad Autónoma de Baja California Sur, Apartado Postal 19-B, La Paz, Baja California Sur, México, C.P. 23080.
}

Pacific Science (2007), vol. 61, no. 4:575-586

(C) 2007 by University of Hawai'i Press

All rights reserved the number of medullary cells, where Dilophus is characterized by one to six medullary cells, and Dictyota presents more than one in some parts of the thallus. This has resulted in difficulties in drawing the boundaries between genera such as Dilophus J. Agardh, Glossophora J. Agardh, Glossophorella Nizamuddin \& Campbell, and Pachydictyon J. Agardh. The differentiation between Dictyota and Dilophus is still debated, although several authors have accepted the merger of both genera as formally proposed by Hörnig et al. $(1992 a, b)$ (e.g., Silva et al. 1996, Wynne 1998, De Clerck and Coppejans 2003). Two recent studies (Lee and Bae 2002, Hoshina et al. 2004) using molecular markers to evaluate the distinction of Dilophus and Dictyota point toward the recognition of two genera. However, in both studies only one Dilophus species was used, so these results should be interpreted with great care. In contrast, molecular analyses by De Clerck et al. (2006) suggested a lack of differences between DictyotaDilophus-Glossophora-Pachydictyon.

In studies of seaweeds from tropical and temperate locations, Norton et al. (1981) observed that thallus length is smaller in tropical 
locations than in temperate locations. The Gulf of California presents a geographical cline in temperature and irradiance along its range (Santamaría-del-Ángel et al. 1994, Riosmena-Rodríguez et al. 2001). Therefore, the Gulf of California is a good region to understand the ecological and physiological limits of genera and species, and if there are any vegetative or reproductive trends. Hwang et al. (2005) observed differences in the proportion of sporophytes and gametophytes of a Korean Dictyota species along a longitudinal gradient. These trends could be related to biogeographical distribution of the different species composing the benthos (Roden 1964, Santamaría-del-Ángel et al. 1994).

Dictyota crenulata J. Agardh is one of the most common species in the Gulf of California (Riosmena-Rodríguez 2005), and therefore it was the focus of this study. The aims were to evaluate the morphological variability of $D$. crenulata between central western and southwestern populations in the Gulf of California and determine whether differences in morphology and reproduction between localities follow a geographical pattern.

\section{MATERIALS AND METHODS}

Sampling was carried out between March and June 2000 at seven localities in the southwestern and central western regions of the Gulf of California. During that time of year thalli were fully developed and reproductive. The localities sampled in the southwestern region were Punta El Camarón $\left(24^{\circ} 19^{\prime} 6.2^{\prime \prime} \mathrm{N}, 110^{\circ}\right.$ $\left.38^{\prime} 33.2^{\prime \prime} \mathrm{W}\right)$, El Tecolote $\left(24^{\circ} 21^{\prime} 4.5^{\prime \prime} \mathrm{N}\right.$, $\left.110^{\circ} 15^{\prime} 45.8^{\prime \prime} \mathrm{W}\right)$, Punta Coyote $\left(24^{\circ} 19^{\prime}\right.$ $48^{\prime \prime} \mathrm{N}, 110^{\circ} 13^{\prime} 48^{\prime \prime} \mathrm{W}$ ), and El Sargento $\left(24^{\circ} 6^{\prime} 6^{\prime \prime} \mathrm{N}, 109^{\circ} 59^{\prime} 20^{\prime \prime} \mathrm{W}\right)$ (Figure 1). The central western region included Roca

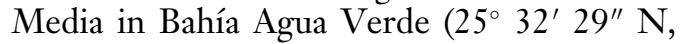
$111^{\circ} 7^{\prime} 40^{\prime \prime} \mathrm{W}$ ) and Loreto (26 $00^{\circ} 55^{\prime \prime} \mathrm{N}$, $111^{\circ} 20^{\prime} 19^{\prime \prime} \mathrm{W}$ ) and Los Pocitos in Bahía Concepcion $\left(26^{\circ} 33^{\prime} 25.3^{\prime \prime} \mathrm{N}, 111^{\circ} 45^{\prime} 15.5^{\prime \prime}\right.$ $\mathrm{W})$ (Figure 1). These sites, all of which are 1-5 $\mathrm{m}$ deep, are well known for their high abundance of $D$. crenulata. At each locality, two transects (50 m long) were located parallel to the shore at $2-3 \mathrm{~m}$ depth, and 15 thalli were collected randomly along each transect.
Samples were fixed in a formalin-seawater solution (4\%). A total of 180 thalli was collected and analyzed, but in Los Pocitos and Punta Coyote only 15 thalli were available.

Vegetative and reproductive variability were assessed by analyzing several morphological and anatomical features. Thallus length and width (basal, middle, and apical portion) were measured. The number of surface and marginal proliferations in the thallus was counted for three randomly selected quadrants $\left(1 \mathrm{~cm}^{2}\right)$. The number of mature and vegetative thalli was counted, and the proportions of each life cycle stage (sporophyte and gametophyte) were calculated. Transverse sections were made at the basal, middle, and apical regions to determine the number of medullary and cortical cells, taking note of their form and size (height and width). The basal and apical sections of the proliferations were analyzed with the same methodology. The arrangement, shape, and size (height and width) of the oogonial sori and sporangia were determined using transverse sections of the thalli that presented reproductive structures.

Data were analyzed statistically: first, normality (Kolmogorov-Smirnov and Lilleifors test) and homocedasticity (Barlett test) were evaluated in all the data (Zar 1996). Because assumptions were not met, an analysis of variance on ranks (Kruskal-Wallis) was used. Finally, multiple comparison procedures (Dunn's test) (Zar 1996) were used to determine differences between localities. Differences in the proportions of each life cycle stage by region were analyzed by a $t$-test. All the material is housed at the Phycological Herbarium of the Autonomous University of Baja California Sur (ғвсs).

\section{RESULTS}

\section{Vegetative Variability}

The range of all the measures overlapped among localities (Table 1). Morphological and anatomical differences were found between sites in the two regions. The number and position of proliferations did not differ between the southwestern (mean $12 \pm 5.86$ 


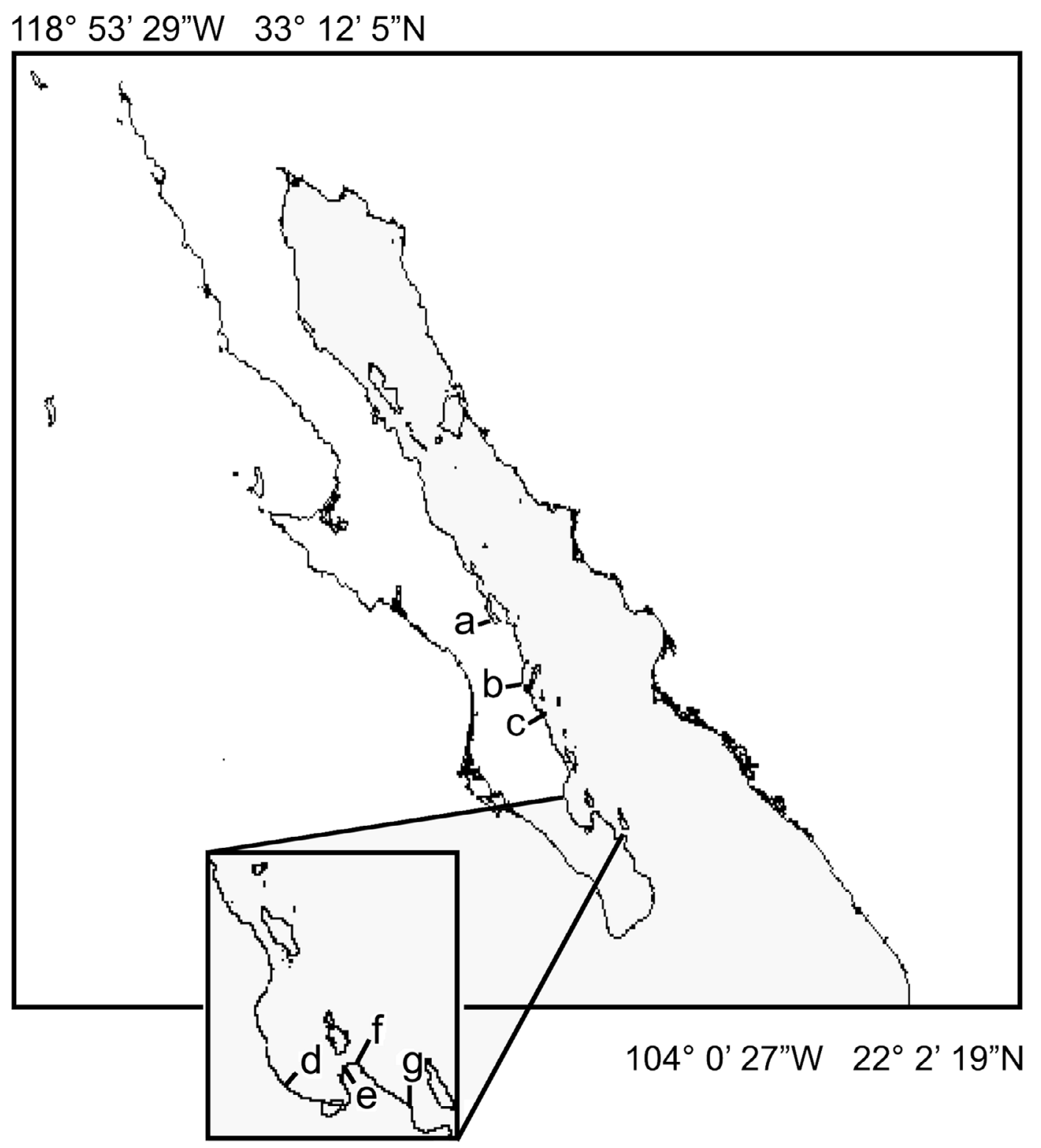

FIGURE 1. Localities sampled along the central western and southwestern Gulf of California. Central western region: $a$, Los Pocitos, Bahía Concepción; $b$, Loreto; $c$, Roca Media, Bahía Agua Verde. Southwestern region: $d$, Rancho El Camarón, Bahía de La Paz; e, El Tecolote, Bahía de La Paz; f, Punta el Coyote, Bahía de La Paz; g, El Sargento, Bahía de la Ventana.

proliferations per quadrant) and the central western region (mean $12.33 \pm 4.97$ proliferations per quadrant). Southwestern thalli had larger proliferations at the margin and surface positions (Figure $2 A$ ), and thalli from the central region had shorter proliferations in the middle section of the plant in the same areas (Figure $2 B, C$ ). 
TABLE 1

Range in Measurements of Dictyota crenulata from Central and Southwestern Regions in the Gulf of California

\begin{tabular}{llcccc}
\hline \hline & & \multicolumn{3}{c}{ Morphological Vegetative } \\
\cline { 3 - 6 } & & & \multicolumn{3}{c}{ Width $(\mathrm{cm})$} \\
\cline { 3 - 6 } Region & \multicolumn{1}{c}{ Locality } & Length $(\mathrm{cm})$ & Basal & Middle & Apical \\
\hline \multirow{2}{*}{ Central western } & Los Pocitos & $4-11$ & $0.1-0.38$ & $0.1-0.55$ & $0.04-0.15$ \\
& Loreto & $2.5-6$ & $0.05-0.27$ & $0.14-0.27$ & $0.03-0.12$ \\
Southwestern & Roca Media & $5-13$ & $0.15-0.44$ & $0.13-0.5$ & $0.02-0.1$ \\
& Punta El Camarón & $4-12$ & $0.17-0.36$ & $0.13-0.32$ & $0.02-0.11$ \\
& Tecolote & $5-15$ & $0.2-0.44$ & $0.18-0.37$ & $0.02-0.09$ \\
& Punta Coyote & $4-15$ & $0.16-0.3$ & $0.13-0.33$ & $0.04-0.12$ \\
& El Sargento & $8-25$ & $0.15-0.5$ & $0.12-0.4$ & $0.03-0.08$ \\
\hline
\end{tabular}

Results from Kruskal-Wallis tests indicated significant differences between each locality's mean. Thallus length differed significantly between El Sargento and Loreto according to Dunn's tests $(H=119.8$, $P<.001$ [Figure $3 A]$ ). El Tecolote and El Sargento had wider thalli basal sections than those at Loreto, Roca Media, and Punta El Camarón $(H=55.1, P<.001)$, but those at Los Pocitos were similar to those at all localities (Figure $3 B$ ). The middle width of thalli was different within localities $(H=86.7$, $P<.001)$, and that at Roca Media was different from those at the other localities (Figure $3 B$ ). Apical width of thalli at Roca Media and Los Pocitos was different from those at all other localities but not from each other $(H=91.5, P<.001$ [Figure $3 B])$.

Unilayered and multilayered medullas were found in different sections of the same thallus for all the localities (Figure $4 A, B$ ). Some thalli presented multilayered medullas (up to four cells thick) in the basal sections and in all the proliferations of the apical region. Considering the number of cell layers in the medulla from the basal portion of the thallus, we found a double medulla most frequently (Figure $5 A$ ), and a monostromatic medulla was present in only two localities. A four-layer medulla was present in some specimens from all localities except Punta Coyote, where only one thallus contained a four-layer medulla.

\section{Reproductive Variability}

Vegetative thalli were more dominant in the southwestern region (14\%) than in the central region (3\%) (Figure 5B). A z-test indicated a significant difference in the proportions between regions $(z=2.64, P=.004$, $n=180)$. Punta Coyote presented the highest proportion of vegetative thalli $(30 \%)$, and in Loreto we did not observe any vegetative thalli (Figure $5 C$ ).

Female thalli presented groups of 30 to 45 rounded oogonia on the surface and four to six oogonia in transverse section (Figure $6 A$ ). Loreto had the highest proportion of female thalli (23\%), and Punta Coyote (southwestern region) presented the lowest proportion (3\%) (Figure $5 C$ ). Sporangia were rounded and solitary (Figure 6B), although some sori with two sporangia were observed. El Tecolote had the highest proportion of sporophyte thalli (22\%), and Punta Coyote presented the lowest (4\%) (Figure 5C). Female and sporophyte thalli were more abundant in the southwestern region (22\%) (Figure 5B). In the central region, proportion female and proportion sporophyte (both 18\%) 


\begin{tabular}{|c|c|c|c|c|c|c|c|c|}
\hline \multicolumn{5}{|c|}{ Anatomical Vegetative } & \multicolumn{4}{|c|}{ Anatomical Reproductive } \\
\hline \multicolumn{2}{|c|}{$\begin{array}{l}\text { Cortical Cells } \\
\qquad(\mu \mathrm{m})\end{array}$} & \multicolumn{2}{|c|}{$\begin{array}{l}\text { Medullary cells } \\
\qquad(\mu \mathrm{m})\end{array}$} & \multirow{2}{*}{$\frac{\begin{array}{c}\text { Oogonial Sori } \\
(\mu \mathrm{m})\end{array}}{\text { Width }}$} & \multicolumn{2}{|c|}{$\begin{array}{c}\text { Oogonia } \\
(\mu \mathrm{m})\end{array}$} & \multicolumn{2}{|c|}{$\begin{array}{c}\text { Sporangia } \\
(\mu \mathrm{m})\end{array}$} \\
\hline Height & Width & Height & Width & & Height & Width & Height & Width \\
\hline $8-22$ & $9-19$ & $18-112$ & $40-88$ & $95-114$ & $42-59$ & $18-45$ & $28-35$ & $31-68$ \\
\hline $8-22$ & $9-24$ & $65-81$ & $44-75$ & 64-222 & $29-72$ & $13-44$ & $19-55$ & $22-57$ \\
\hline $6-25$ & $9-29$ & $43-104$ & $47-118$ & $55-174$ & $17-74$ & $21-50$ & $18-76$ & $20-83$ \\
\hline $10-19$ & $9-26$ & $42-105$ & $50-147$ & $69-240$ & $38-71$ & $19-43$ & $31-61$ & $29-73$ \\
\hline $8-20$ & $11-27$ & $31-140$ & $33-101$ & $66-225$ & $10-87$ & $16-52$ & $41-60$ & $32-59$ \\
\hline $8-19$ & $12-21$ & $44-93$ & $40-93$ & $99-117$ & $42-55$ & $21-29$ & $12-73$ & $13-55$ \\
\hline $16-23$ & $10-25$ & $46-103$ & $87-118$ & $64-165$ & $32-106$ & $16-64$ & $27-101$ & $25-101$ \\
\hline
\end{tabular}

were not significantly different (female: $P=$ $0.1648, \quad \mathrm{z}=0.97$; sporophyte: $P=0.1357$, $\mathrm{z}=1.10)$.

\section{DISCUSSION}

Genera and species of the Dictyotales are largely defined by differences in morphology and vegetative anatomy (Phillips 1997), which may result in unreliable classification. Dictyota and Dilophus have been differentiated based on the number of cell layers in the medulla (Womersley 1987). The arrangement of the medulla in our study was not consistent in all thalli; both unilayered and multilayered medullas (up to four cells) were found in some basal parts of thalli and proliferations (Figure $4 A, 5 A$ ). These results are consistent with those of Hörnig et al. (1992a) for 18 taxa of Dictyota and Dilophus. The segregation of both genera based on their medullary arrangement is not reliable. De Clerck (2003) observed similar variation in the medullas of Dictyota robusta J. Agardh, D. subrii G. Murray, and $D$. radicans. Therefore, the analysis of morphological variations and their consistency between and within populations is fundamental for the segregation of $D$. crenulata from other regional species. It seems that the numbers of medullary cells may vary across populations, which could be in response to the drag forces in the habitat or nutrient concentration. Hörnig et al. (1992b) observed that increases in nutrient concentration were associated with increased cell numbers. An equivalent situation is present in the geniculate coralline algae, where in the basal intergenicula and genicula of any single specimen the number of cells increased relative to the rest of the thallus (Rivera-Campos and Riosmena-Rodríguez 2003).

Also, a geographical trend was reflected in thallus length and apical width; shorter and wider thalli dominated central localities such as Roca Media. This pattern is contrary to that observed in the temperate red alga Corallina vancouverensis Yendo (RiosmenaRodríguez and Siqueiros-Beltrones 1995) and the endemic brown alga Cutleria hancockii Dawson (Riosmena-Rodríguez et al. 2001), where thalli in southern regions are shorter and narrow. Geographical variation in thallus morphology has been observed previously for other regions. Hwang et al. (2005) reported changes in the thallus width of Dictyota dichotoma (Hudson) Lamouroux on the coast of Korea as a result of environmental conditions at each locality. Malbrán and Hoffmann (1990) indicated that temperature affects growth rate along the latitudinal distribution of the species. Norton et al. (1981) suggested that thallus length has been reported to be shorter toward tropical locations due to environmental factors, principally temperature. 

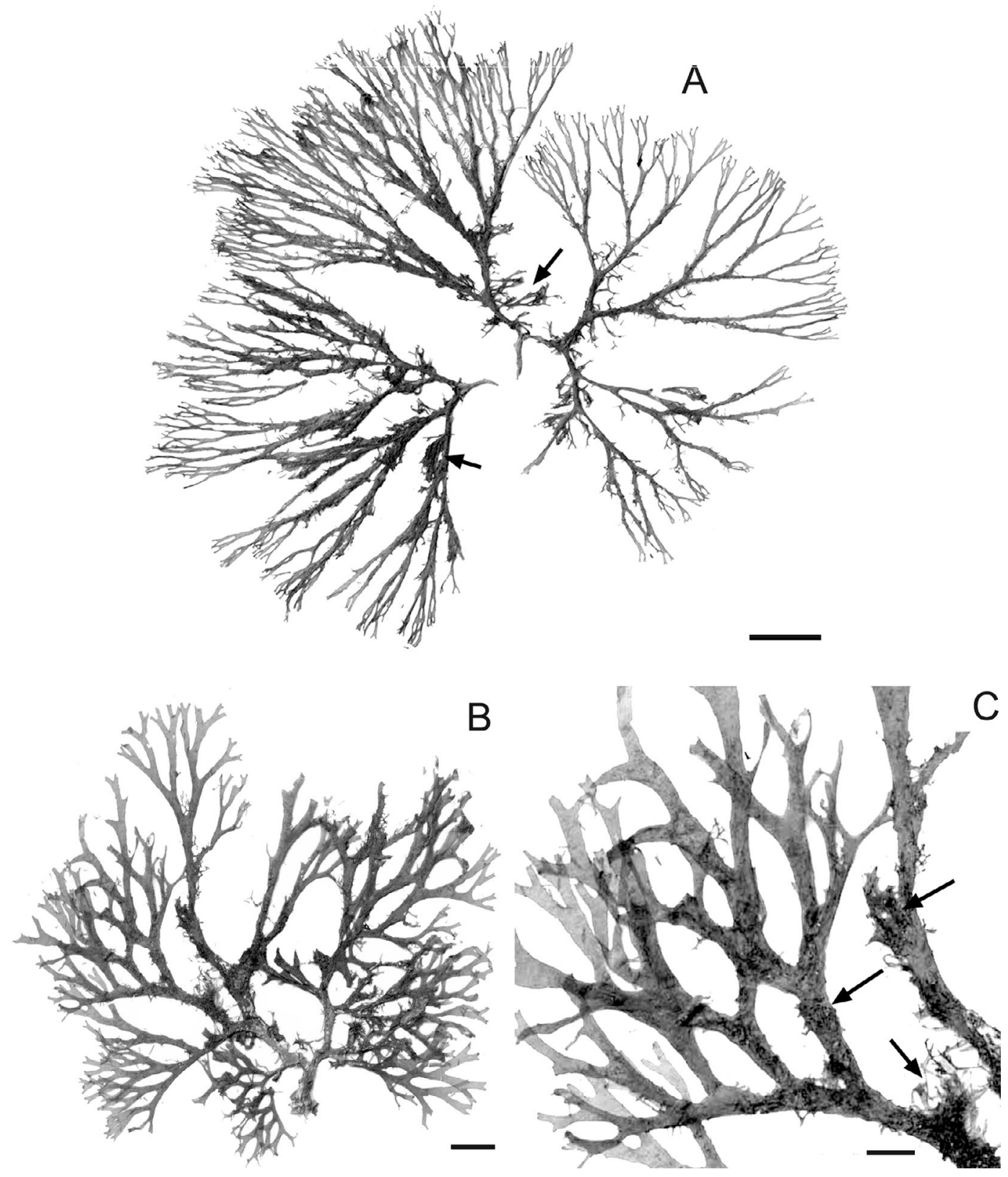

FIGURE 2. Vegetative morphology of Dictyota crenulata. A, Thallus from the southwestern region showing proliferations (arrows) in margin and surface areas (ғвсs-2230, scale $1 \mathrm{~cm}) ; B$, thallus from the central western region showing fewer proliferations in both positions (FBCs-2228, scale $1 \mathrm{~cm}$ ); $C$, detail of $B$ showing proliferations (arrows) in marginal and surface positions $($ scale $1 \mathrm{~cm}$ ). 


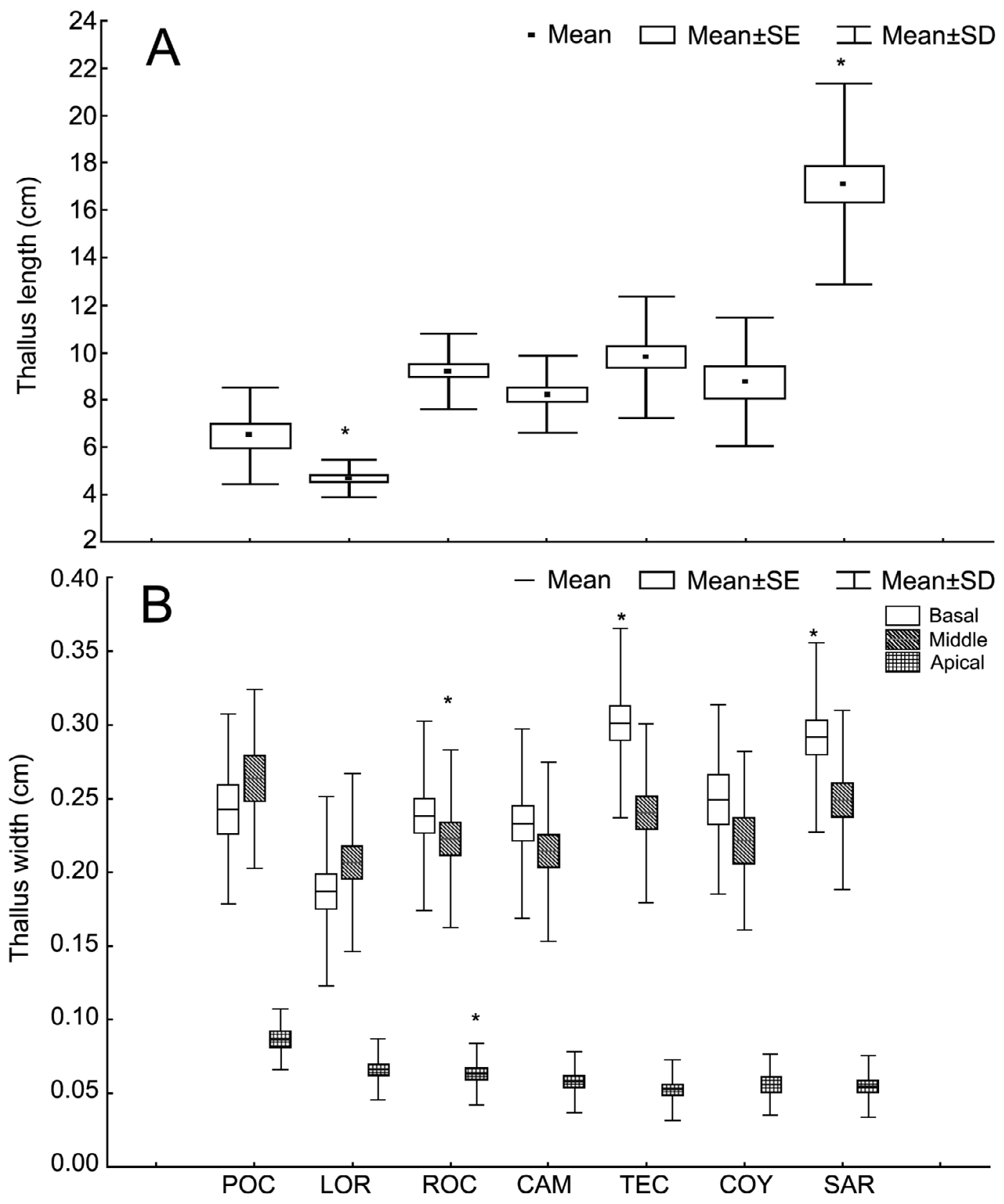

Figure 3. Morphometric analysis of Dictyota crenulata by localities. $A$, Mean, standard deviation (SD), and standard error (SE) of thalli length. Asterisks denote localities that differed significantly according to Dunn's test $(P<.0001)$. Sites are ordered from north to south: Los Pocitos (POC), Loreto (LOR), Roca Media (ROC), Punta El Camarón (CAM), El Tecolote (TEC), Punta Coyote (COY), and El Sargento (SAR); $B$, mean, SD, and SE of the basal, middle, and apical width of thalli. Asterisks denote localities with significant differences according to Dunn's test $(P<.0001)$. 


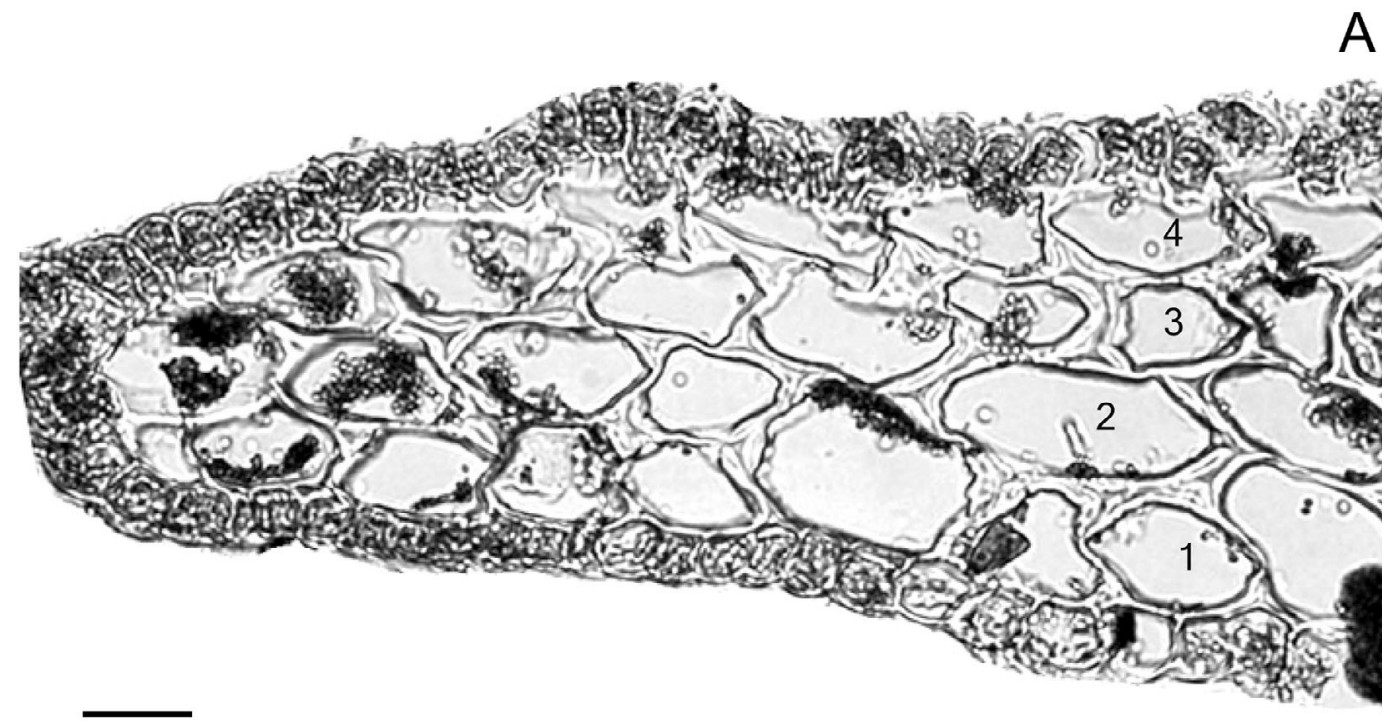

B

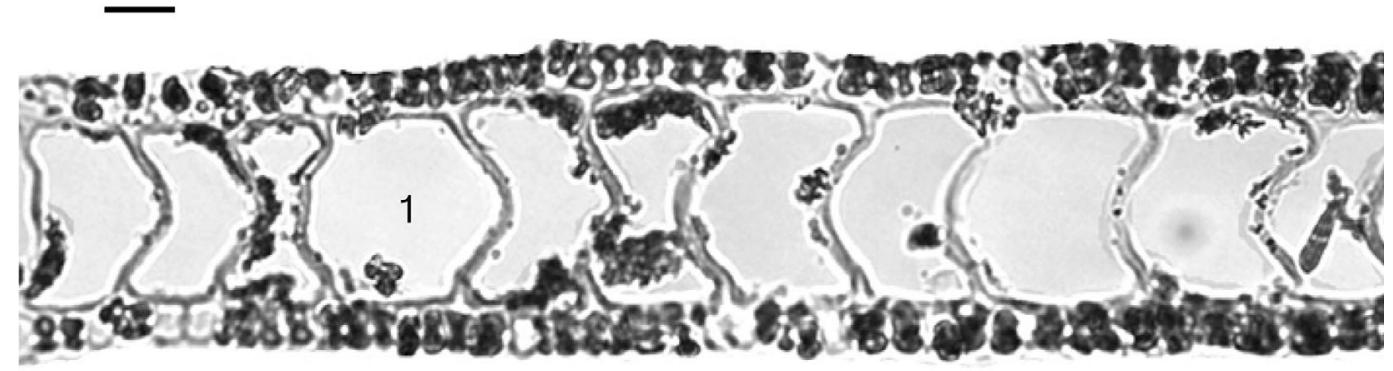

FIgURE 4. Anatomy of a vegetative Dictyota crenulata thallus. $A$, Transverse section of the basal portion showing multilayered medulla four cells (numbers) thick (ғвсs-2231, 20×, scale $100 \mu \mathrm{m}$ ); $B$, transverse section of middle portion of thallus showing a unilayered (number) medulla (ғвсs-2231, 20×, scale $100 \mu \mathrm{m}$ ).

Based on the short distance between regions in our study, the water temperature differences between the central and southwestern region $\left(1\right.$ or $3^{\circ} \mathrm{C}$ in the seasons that we sampled) are probably not relevant (SotoMardones et al. 1999, Castro et al. 2000). We performed a regression analysis and found no significant relationship between temperature and thallus length $\left(R^{2}=0.23\right.$, $P<.275$ ), but the general trend (Figure $3 A$ ) is opposite to that reported by Norton et al. (1981); average thallus length seemed to increase with increasing temperature, which ranged from $20^{\circ} \mathrm{C}$ at Los Pocitos up to $23^{\circ} \mathrm{C}$ at El Sargento.

Dictyota crenulata presented differences in the life cycle along the study area. Vegetative thalli were more abundant in the southern localities (Punta Coyote and El Sargento). In the central localities, Loreto and Roca Media were dominated by gametophyte thalli (female) and sporophyte thalli, respectively. However, both were dominant in the southwestern region, with the gametophyte stage the most abundant $(22 \%, n=180)$, which has also been reported for several other species 

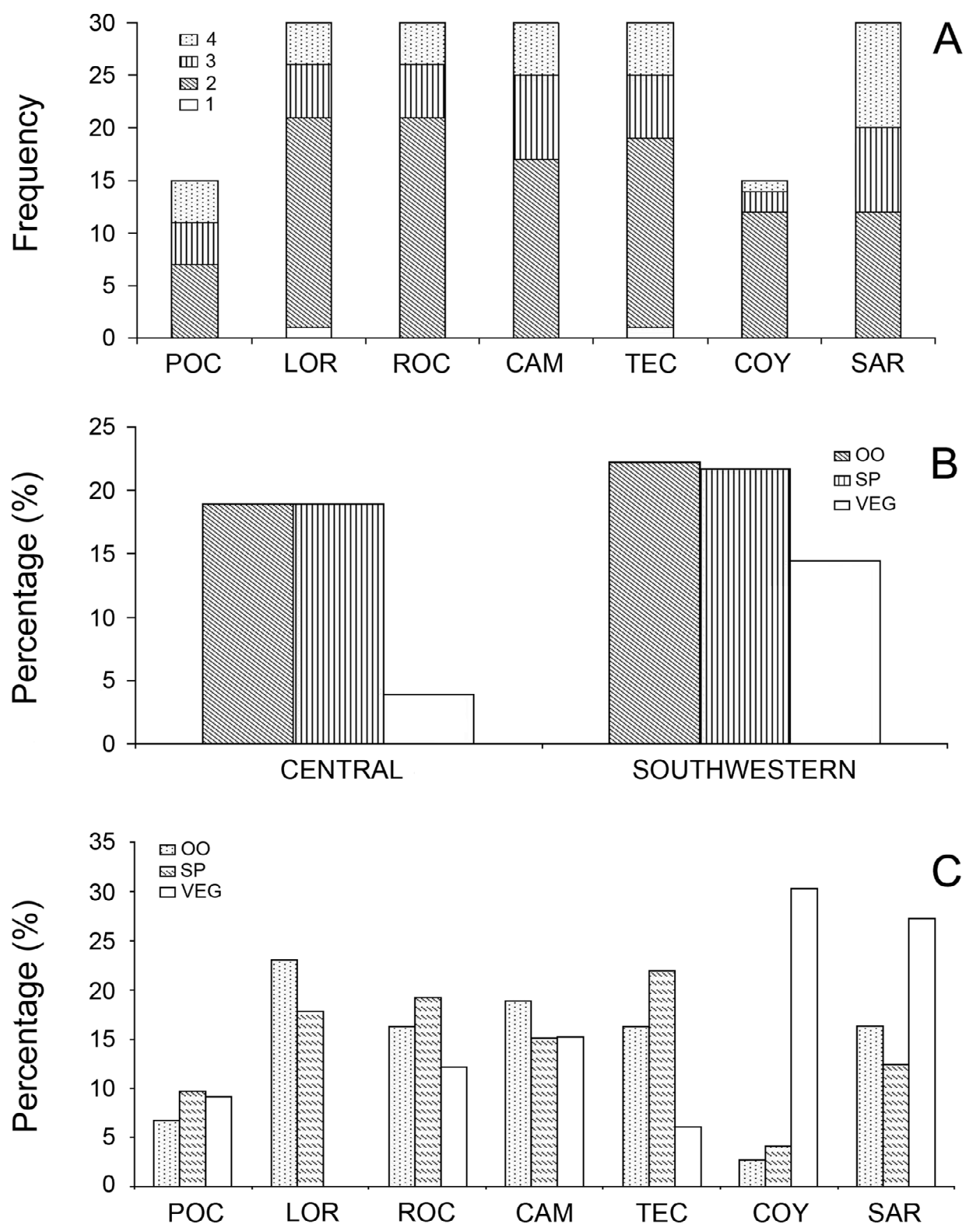

FIGURE 5. Frequency of the medullary arrangement in the basal portion of thalli and percentage of reproductive status of Dictyota crenulata thalli by region and locality. $A$, Frequency by locality of the medullary arrangement in the basal portion of thalli. Numbers (1-4) indicate the number of medullary cells; $B$, percentage of reproductive stages by region: the southwestern region presented the highest percentage of all life cycle stages, female (OO), sporangial (SP), and vegetative (VEG) thalli; $C$, Loreto (LOR) presented a higher proportion of female thalli; Punta Coyote (COY) was dominated by vegetative thalli; El Tecolote (TEC) had higher numbers of sporophytic thalli. POC, Los Pocitos; ROC, Roca Media; CAM, Punta El Camarón; SAR, El Sargento. 


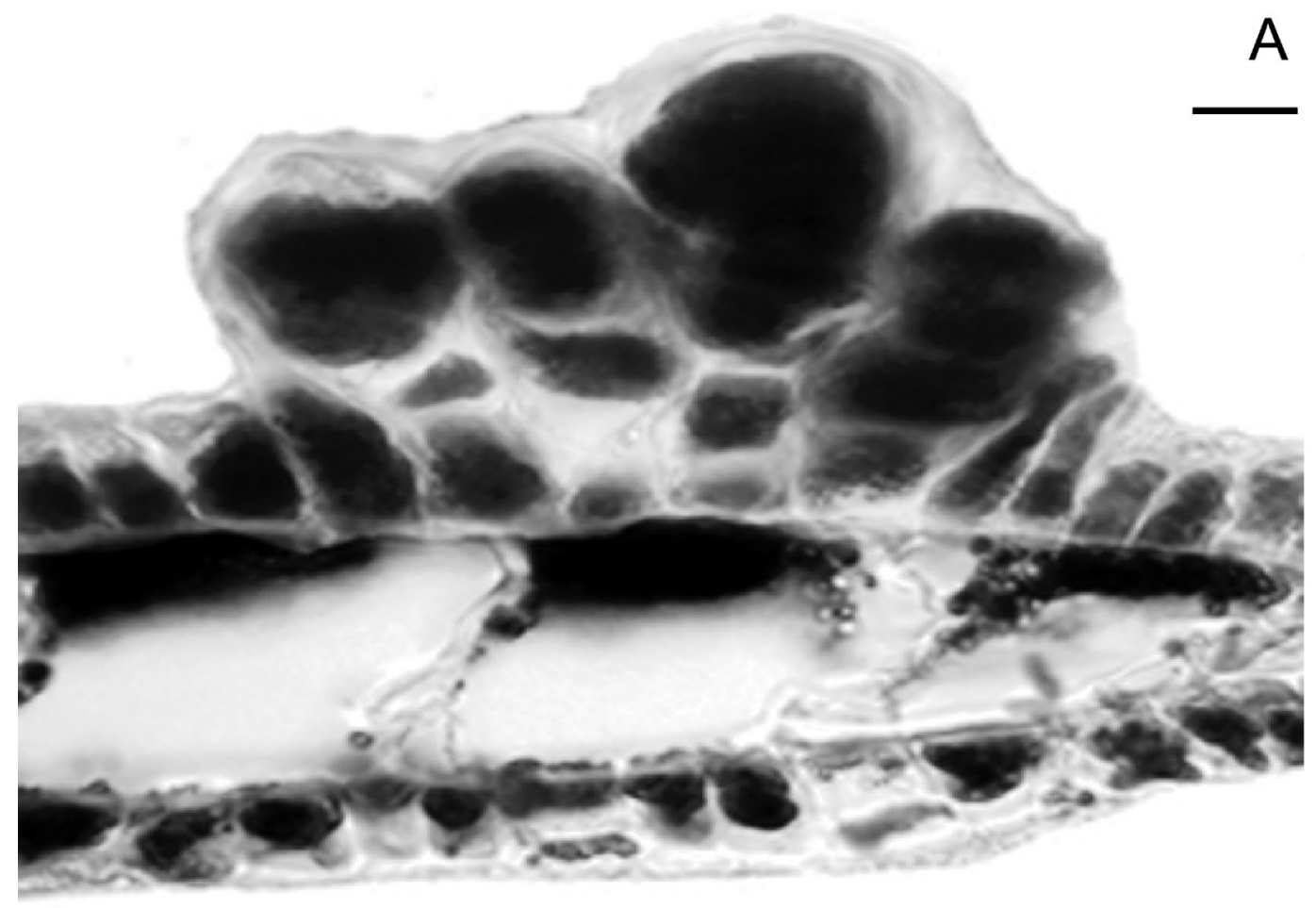

A

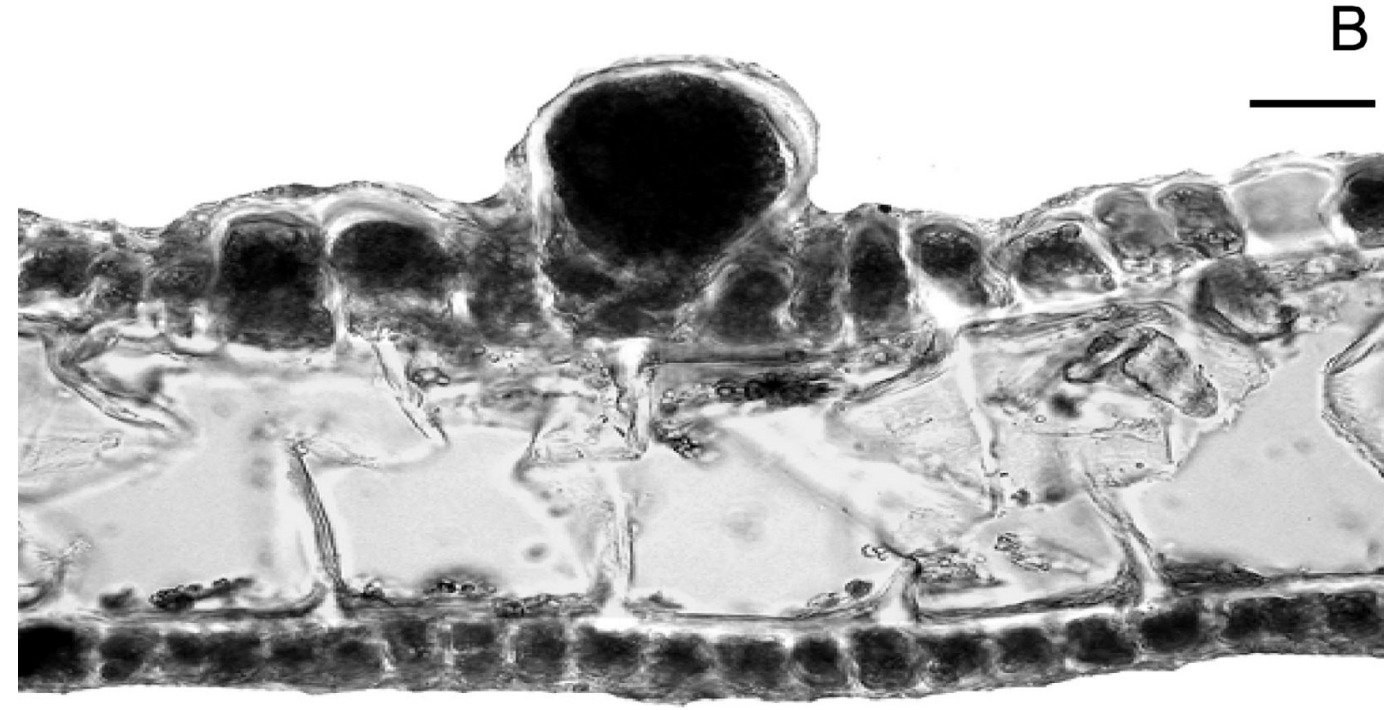

Figure 6. Anatomy of a reproductive Dictyota crenulata thallus. $A$, Transverse section showing the arrangement in sori of four ovate oogonia, each one arising from a single cortical cell (ғвсs-2227, 20×, scale $100 \mu \mathrm{m}$ ); $B$, transverse section showing solitary rounded tetrasporangium (Fвсs-2236, 20×, scale $50 \mu \mathrm{m}$ ). 
of Dictyotales [e.g., Dictyota dichotoma (Hudson) Lamouroux and Glossophora kunthii (C. Agardh) J. Agardh] (King and Farrant 1987, Malbrán and Hoffmann 1990). Hwang et al. (2005) found differences in the proportions of sporophytes and gametophytes depending on the region.

Our results demonstrate that Dictyota crenulata presents morphological variation across its distribution in the Gulf of California. More detailed studies are necessary to understand the underlying factors that are responsible for this morphological variation.

\section{ACKNOWLEDGMENTS}

We thank the staff of the Marine Botany Laboratory (FBCS) for their assistance in the field. We also thank two anonymous reviewers for their comments. We are thankful to T. Ireton, F. Riosmena-Rodríguez, and G. Hinojosa-Arango for reviewing the English version of the paper.

\section{Literature Cited}

Castro, R., A. S. Mascarenhas, R. Durazo, and C. A. Collins. 2000. Seasonal variation of the temperature and salinity at the entrance to the Gulf of California, Mexico. Cienc. Mar. 26:561-583.

De Clerck, O. 2003. The Indian Ocean species of Dictyota (Dictyotales, Phaeophyta). Opera Bot. Bel. 13:1-169.

De Clerck, O., and E. Coppejans. 1999. Two new species of Dictyota (Dictyotales, Phaeophyta) from the Indo-Malayan region. Phycologia 38:184-194.

- 2003. Morphology and systematics of two aberrant species of Dictyota (Dictyotaceae, Phaeophyta), including a discussion on the generic boundaries in the tribe Dictyoteae. Pages 275-284 in A. R. O. Chapman, R. J. Anderson, V. J. Vreel, and I. R. Davison, eds. Proc. 17th Int. Seaweed Symp., Cape Town. Oxford University Press, New York.

De Clerck, O., F. Leliaert, H. Verbruggen, C. Lane, J. Campos de Paula, D. A. Payo, and E. Coppejans. 2006. A revised classification of the Dictyoteae (Dictyotales,
Phaeophyceae) based on rbcL and 26S ribosomal DNA sequence analyses. J. Phycol. 42:1271-1288.

Hörnig, I., R. Schnetter, and W. F. Prud'homme van Reine. 1992a. The genus Dictyota (Phaeophyceae) in the North Atlantic. I. A new generic concept and new species. Nova Hedwigia 54:45-62.

. 1992b. The genus Dictyota (Phaeophyceae) in the North Atlantic. II. Key to the species. Nova Hedwigia 54:397402.

Hoshina, R., K. Hasegawa, J. Tanaka, and Y. Hara. 2004. Molecular phylogeny of the Dictyotaceae (Phaeophyceae) with emphasis on their morphology and its taxonomic implication. Jpn. J. Phycol. 52 (Supplement): 189-194.

Hwang, I. K., H. S. Kim, and W. J. Lee. 2005. Polymorphism in the brown alga Dictyota dichotoma (Dictyotales, Phaeophyceae) from Korea. Mar. Biol. (Berl.) 147:999-1015.

King, R. J., and P. A. Farrant. 1987. The phenology of the Dictyotales (Phaeophyceae) at a sheltered locality in Sydney Harbor, New South Wales, Australia. Bot. Mar. 30:341-350.

Lee, W. J., and K. S. Bae. 2002. Phylogenetic relationship among several genera of Dictyotaceae (Dictyotales, Phaeophyceae) based on $18 \mathrm{~S}$ rRNA and partial rbcL gene sequences. Mar. Biol. (Berl.) 140:11071115.

Malbrán, M. E., and A. J. Hoffmann. 1990. Seasonal cycles of growth and tetraspore formation in Glossophora kuntbii (Phaeophyta, Dictyotales) from Pacific South America: Field and laboratory studies. Bot. Mar. 33:219-223.

Norton, T. A., A. C. Mathieson, and M. Neushul. 1981. Morphology and environment. Pages 421-451 in C. S. Lobban and M. J. Wynne, eds. The biology of seaweeds. Blackwell Scientific Publications, Oxford.

Phillips, J. A. 1997. Genus and species concepts on Zonaria and Homoestrichus (Dictyotales, Phaeophyceae), including the description of Exallosorus gen. nov. Eur. J. Phycol. 32:303-311. 
Riosmena-Rodríguez, R. 2005. ¿Existen especies de algas verdes y cafés del Golfo de California que deban estar en la NOM059? Informe técnico final. Comisión $\mathrm{Na}$ cional para el Conocimiento y Uso de la Biodiversidad (CONABIO) V054.

Riosmena-Rodríguez, R., and D. A. Siqueiros-Beltrones. 1995. Morfología y distribución de Corallina vancouveriensis (Corallinales, Rhodophyta) en el Pacífico Noreste. Cienc. Mar. 20:187-199.

Riosmena-Rodríguez, R., L. Paul-Chávez, and G. Hinojosa-Arango. 2001. Range extension of Cutleria bancockii Dawson (Cutleriales, Phaeophyta) to the southwestern Gulf of California, Mexico. Bot. Mar. 44:461-465.

Rivera-Campos, R., and R. RiosmenaRodríguez. 2003. Size class distribution and reproduction of Amphiroa vanbosseae (Corallinales; Rhodophyta) in southwestern México. Algae 18:59-63.

Roden, G. I. 1964. Oceanographic aspects of the Gulf of California. In T. H. van Andel and G. G. Shor, Jr. Marine geology of the
Gulf of California: A symposium. Am. Assoc. Pet. Geol. Mem. 3:30-58.

Santamaría-del-Ángel, E., S. ÁlvarezBorrego, and F. E. Muller-Karger. 1994. Gulf of California biogeographic regions based on coastal zone color scanner imagery. J. Geophys. Res. 99:7411-7421.

Silva, P. C., P. W. Basson, and R. L. Moe. 1996. Catalogue of the benthic marine algae of the Indian Ocean. Univ. Calif. Publ. Bot. 79:1,259 pp.

Soto-Mardones, L., S. G. Marinone, and A. Parés-Sierra. 1999. Time and spatial variability of sea surface temperature in the Gulf of California. Cienc. Mar. 25:1-30.

Womersley, H. B. S. 1987. The marine benthic flora of southern Australia. Part II. South Australia Government Printing Division, Adelaide.

Wynne, M. J. 1998. A checklist of benthic marine algae of the tropical and subtropical western Atlantic: First revision. Nova Hedwigia 116:iii + 151 pp.

Zar, J. H. 1996. Biostatistical analysis. Prentice Hall, Englewood Cliffs, New Jersey. 